ISSN 0103-5150

Fisioter. Mov., Curitiba, v. 27, n. 3, p. 437-445, jul./set. 2014

Licenciado sob uma Licença Creative Commons DOI: http://dx.doi.org.10.1590/0103-5150.027.003.A015

\title{
Prevalence of postural alterations in students of Basic Education in the city of Vila Velha, Espírito Santo state, Brazil
}

\author{
Prevalência de alterações posturais em escolares \\ de Ensino Fundamental de Vila Velha (ES)
}

\section{Paula Lopes Rodrigues ${ }^{[a]}$, Eloá Ferreira Yamada ${ }^{[b]}$}

[a] PhD candidate, Universidade Federal do Espírito Santo (UFES), Vitória, ES - Brazil, e-mail: paulal.r.vix@terra.com.br

[b] MSc, professor, Universidade Federal do Pampa (Unipampa), Uruguaiana, RS - Brazil, e-mail: eloayamada@unipampa.edu.br

\begin{abstract}
Introduction: Human posture goes through a series of changes in the course of body growth and development, i.e., in childhood and adolescence. Moreover, during these phases, individuals are subject to risk behaviors for spinal problems, especially those related to the use of backpacks and to poor sitting posture. Objective: This study aimed to detect the prevalence of postural alterations in school children enrolled in the UMEF Vila Olímpica, Vila Velha, Espírito Santo. Methods: We evaluated 513 schoolchildren in the orthostatic position and in the anterior, posterior and side view. The following structures were analyzed: head, shoulder, the cervical, thoracic and lumbar spine, pelvis and lower limbs. Results: There was a high prevalence of postural deviations: rotated or tilted head, elevated shoulder and pelvis, valgus or varus knee, head protraction, alterations of the thoracic spine, anteriorized shoulders, pelvis in anteversion, knees semiflexion or hyperextension and cavus or planus feet. Conclusion: Our results suggest that there is a high prevalence of postural alterations in students in the school network of Vila Velha (ES). This could be detected through public health policies, such as the federal government's Health at School Program (PSE).
\end{abstract}

Keywords: Postural Alterations. Schoolchildren. Physical Therapy. 


\section{Resumo}

Introdução: A postura do ser humano apresenta uma série de mudanças no decorrer do crescimento e desenvolvimento corporais, ou seja, na infância e na adolescência. Além disso, durante essas fases, os indivíduos estão sujeitos a comportamentos de risco para a coluna, principalmente aqueles relacionados à utilização de mochilas e à postura sentada. Objetivo: A finalidade desse trabalho foi verificar a prevalência de alterações posturais em escolares da UMEF Vila Olímpica, Vila Velha, Espírito Santo. Métodos: Foram avaliados 513 escolares na posição ortostática, em vista anterior, posterior e perfil, no qual foram analisadas as seguintes estruturas: cabeça, ombro, colunas cervical, torácica e lombar, pelve e membros inferiores. Resultados: Os resultados apresentaram uma grande prevalência de desvios posturais: cabeça rodada ou inclinada, elevação do ombro e da pelve, joelho valgo ou varo, além de cabeça em prostração, alterações da coluna torácica, ombros anteriorizados, pelve em anteroversão, joelhos em semiflexão ou hiperextensão, e pés cavos ou planos. Conclusão: Os resultados sugerem que há uma alta prevalência de alterações posturais em escolares na rede de ensino do município, o que poderia ser identificado através de políticas públicas de saúde, como o Programa Saúde na Escola (PSE) do governo federal.

Palavras-chave: Alterações Posturais. Escolares. Fisioterapia.

\section{Introduction}

Posture can be defined as a relative disposition of body parts in which there is a state of muscular and skeletal balance, since it allows the individual to meet the mechanical requirements of the locomotor system, maintaining the upright position with minimal muscular effort (1). Good posture is maintained by a balance between strength and muscle stretching, by a proper functioning of the joints, gravity line balance and good postural habits, contributing to the health of the individual $(1,2)$.

Human posture goes through a series of changes in the course of body growth and development, i.e., in childhood and adolescence $(3,4)$. Moreover, during these phases, individuals are subject to risk behaviors for spinal problems, especially those related to the use of backpacks and to poor sitting posture (5).

The Law of Guidelines and Bases of Education states that all children must be enrolled in basic education. Thus, during at least eight years, every child of school age will remain in the seated position for about four to five hours a day. These children will adopt different postural patterns while sitting and carrying backpacks, and may develop an improper gait, which may result in postural alterations, fatigue and chronic back pain (6). Studies show that children attending traditional school spend more than $95 \%$ of the time at school sitting in a static position $(7,8)$, and spend an average of 1.5 hours a day playing video games and using computers (9).

These behaviors at school and/or during leisure time may cause both lateral and antero-posterior postural alterations $(10,11)$, increasing total stress on body elements and putting higher loads on structures that are less able to bear them. This causes discomfort, pain or disability (2).

Postural alterations may occur at the level of the head, neck, shoulder, pelvis, knees and feet. Spinal disorders can be found by observing an increase in the physiological curvature or the appearance of lateral curvature of the spine (12). The most common deviations are found: in the shoulder (elevation, depression, protrusion and retraction), the scapula (abduction and adduction), the pelvis (tilt, rotation, anteversion and retraction), knees (valgus, varus, hyperextension and flexion) and feet (valgus, varus, abduct, adduct, calcaneus and equinus) (13).

According to Burns and MacDonald (14), children may experience increased tension in certain muscle groups during school time. This is caused by the rapid bone growth that occurs between ages 7 and 12 years, and can be relieved by stretching the affected musculature. However, postural habits adopted in childhood may influence poor posture in adulthood.

Since some postural deviations are detectable in childhood, prevention should start early, minimizing the damaging effects of poor posture and encouraging children to practice healthy habits. Bad postures 
should be avoided, particularly through measures that promote the awareness about attitudes that lead to a better quality of life during growth, development and adulthood (15).

In the last years, the incidence of scoliosis in school children has been widely monitored in the United States. The American Academy of Orthopaedics recommends such monitoring for girls between 11 and 13 years of age and boys between 13 and 14 years of age (16).

Recently, the mayor of São Paulo city sanctioned law number 14758, establishing the Permanent Campaign for Postural Education in Basic Education Schools. Physical therapists carry out a preventive program, making children aware of the importance of adopting correct postures in everyday life (17).

In Vila Velha, Espírito Santo, there are about 35,000 students enrolled in 60 Municipal Units of Primary Education (18). However, to this date, there are no current projects for the detection and prevention of postural alterations, despite the importance of early intervention. Many vertebral disorders are amenable to correction when detected early.

Thus, this study aimed to detect the prevalence of postural alterations in school children enrolled in the Municipal Unit of Primary Education (UMEF) Deputy Mikeil Chequer - Vila Olímpica, Vila Velha, Espírito Santo.

\section{Methods}

This is a cross-sectional descriptive study. It was approved by the Ethics and Research Committee of the Universidade de Vila Velha (No. 43/09). The sample was composed of 513 children enrolled in the 6th-9th grades of the UMEF Vila Olímpica, Vila Velha, Espírito Santo.

Before the assessment, the purpose of this study was explained to the school board and to the children's parents and legal guardians. The latter signed an informed consent form authorizing the children's participation in this study.

Postural assessment was performed using a protocol based on techniques and benchmarks determined by Liposcki, Rosa Neto and Savall (19). Postural analysis was performed in the orthostatic position. In the anterior view, we analyzed the posture of the head, shoulders, right and left anterior-superior iliac spine (ASIS) and knees. In the posterior view, we analyzed the posture of the head and shoulders. In the right and left side views, we observed the posture of the head, shoulders, pelvis, knee, feet, and the spine curvatures.

Postural alterations were analyzed according to the school grades of the students: $6^{\text {th }}$ to $9^{\text {th }}$ grade. The sample was grouped according to school grades in order to compare the prevalence of deviations by age group.

\section{Results}

The results were obtained through assessments conducted on 6-9 graders of both sexes aged between 11 and 15 years and enrolled in the UMEF Vila Olímpica, Vila Velha, Espírito Santo. Two hundred fifty-eight children were male and 255 were female. The results were presented in tables for easy appreciation. The alignment of the head, shoulders, pelvis, knees, feet and spine were described.

We found alterations in the positioning of the head and shoulder in the anterior and posterior views, as shown in Table 1. Children presented tilted head (29.63\%), rotated head $(23.00 \%)$, and rotated and tilted head (23.39\%). Only $23.98 \%$ showed head balance. Prevalence of alterations in the shoulders was $77.78 \%$, which reveals the presence of imbalanced shoulders.

Table 1 - Prevalence of alterations in the positioning of the head and shoulder in the anterior and posterior views

\begin{tabular}{lcc}
\hline $\begin{array}{l}\text { Postural } \\
\text { alterations }\end{array}$ & $\begin{array}{c}\text { Number of } \\
\text { students }\end{array}$ & $\%$ \\
\hline Tilted head & 152 & 29.63 \\
Rotated head & 118 & 23.00 \\
$\begin{array}{l}\text { Rotated and tilted } \\
\text { head }\end{array}$ & 120 & 23.39 \\
Elevated shoulders & 342 & 77.78 \\
\hline
\end{tabular}

Source: Research data.

In the anterior view, we also found alterations related to the leveling of the ASIS and knees, according to Table 2. Three hundred forty two subjects had unleveling of the pelvis, with a prevalence of elevated right or left ASIS, which may indicate the presence 
of lumbar scoliosis or different-sized lower limbs. $66.67 \%$ of the students had imbalanced ASIS: $35.48 \%$ had elevation of the left ASIS and $31.19 \%$ of the right. With regard to alterations in the knee, they were observed in 411 students. Of these, 236 (46.00\%) had valgus knees and 175 (34.11\%) had varus knees.

Table 2 - Prevalence of alterations in the ASIS and knees in the anterior view

\begin{tabular}{lcc}
\hline $\begin{array}{l}\text { Postural } \\
\text { alterations }\end{array}$ & $\begin{array}{c}\text { Number of } \\
\text { students }\end{array}$ & $\%$ \\
\hline ASIS elevation & 342 & 66.67 \\
Valgus knee & 236 & 46.00 \\
Varus knee & 175 & 34.11 \\
\hline
\end{tabular}

Source: Research data.

Regarding the assessment in the side view, 290 subjects had head protraction and 23 had head retraction. We could observe a $61.60 \%$ prevalence of shoulder protrusion among the subjects, which may indicate an improper posture of students with kyphotic positioning of the thoracic spine. In addition, $5.07 \%$ of students had posteriorized shoulders, which may indicate a rectification of the thoracic spine. Associated with head protraction, this characterizes and reflects the adoption of a poor posture, with flexion of the head and shoulders.

Moreover, we found that $28.07 \%$ of the children had cervical rectification and $15.40 \%$ had increased cervical lordosis. One hundred fifty-three $(29.82 \%)$ subjects had thoracic rectification and 127 (24.76\%) had thoracic kyphosis (Table 3).
$58.87 \%$ of the children had pelvis in anteversion and $27.10 \%$ in retroversion. In relation to alterations in the knee, 87 children had knee semiflexion and 174 had knee hyperextension. As for the alterations found in the feet, $17.54 \%$ of subjects had cavus feet and $52.44 \%$ had planus feet (Table 3).

The analysis of the frequency of postural alterations per school grade is presented next. For $6^{\text {th }}$ graders, there was a predominance of tilted head (34.87\%), elevated shoulders (71.05\%), imbalanced ASIS (76.32\%), valgus knee (53.29\%), protracted head $(58.55 \%)$ and shoulders $(63.16 \%)$, rectification of the thoracic spine $(33.55 \%)$, pelvis in anteversion (51.97 \%), knee hyperextension (34.21\%) and planus feet $(61.84 \%)$. For $7^{\text {th }}$ graders, there was a prevalence of rotated and tilted head (32.39\%), elevated shoulders (72.16\%), imbalanced ASIS $(64.20 \%)$, and valgus knee $(48.86 \%)$; in the side view, there was a higher frequency of protracted head (57.39\%) and shoulders (62.50\%), pelvis in anteversion (60.80\%), knee hyperextension (22.16\%) and planus feet $(50.57 \%) .8^{\text {th }}$ graders had rotated head $(31.03 \%)$, elevated shoulders $(67.82 \%)$ and imbalanced ASIS (65.52\%) and varus knee (40.23\%); in side view, we observed protracted head (63.22\%) and shoulders (63.22\%), rectification of the cervical (33.33\%) and thoracic (29.89\%) spines, pelvis in anteversion (64.37\%), knee hyperextension (35.63\%) and planus feet (50.57\%). $9^{\text {th }}$ graders had tilted head (28.57\%), elevated shoulders (66.33\%), imbalanced ASIS (57.14\%), and varus knee (43.88\%); in the side view, we found protracted head (45.92\%) and shoulders (56.12\%), rectification of the cervical (35.71\%) and thoracic $(33.67 \%)$ spines, pelvis in anteversion (61.22\%), knee hyperextension (51.02\%) and planus feet (42.86\%) (Table 4).

Table 3 - Alterations in the positioning of the head, shoulders, neck, cervical and thoracic spines, pelvis, knees and feet in the side view

(To be continued)

\begin{tabular}{lcc}
\hline Postural alterations & Number of students & $\%$ \\
\hline Head protraction & 290 & 56.53 \\
Head retraction & 23 & 4.48 \\
\hline Protruded shoulder & 316 & 61.60 \\
Posteriorized shoulder & 26 & 5.07 \\
\hline Rectification of the Cervical Spine & 144 & 28.07 \\
Cervical lordosis & 79 & 15.40 \\
\hline
\end{tabular}

Fisioter Mov. 2014 jul/set;27(3):437-45 
Table 3 - Alterations in the positioning of the head, shoulders, neck, cervical and thoracic spines, pelvis, knees and feet in the side view

(Conclusion)

\begin{tabular}{lcc}
\hline Postural alterations & Number of students & $\%$ \\
\hline Rectification of the Thoracic Spine & 153 & 29.82 \\
Thoracic kyphosis & 127 & 24.76 \\
\hline Pelvis in anteversion & 302 & 58.87 \\
Pelvis in retroversion & 139 & 27.10 \\
\hline Knee semiflexion & 87 & 16.96 \\
Knee hyperextension & 174 & 33.92 \\
\hline Cavus feet & 90 & 17.54 \\
Planus feet & 269 & 52.44 \\
\hline
\end{tabular}

Source: Research data.

Table 4 - Frequency of postural alterations per school grade

(To be continued)

\begin{tabular}{|c|c|c|c|c|c|c|c|c|}
\hline \multirow{3}{*}{$\begin{array}{l}\text { School grade } \\
\begin{array}{l}\text { Total number of } \\
\text { individuals evaluated }\end{array} \\
\text { Postural Alterations }\end{array}$} & \multicolumn{2}{|c|}{$6^{\text {th }}$ grade } & \multicolumn{2}{|c|}{$7^{\text {th }}$ grade } & \multicolumn{2}{|c|}{$8^{\text {th }}$ grade } & \multicolumn{2}{|c|}{$9^{\text {th }}$ grade } \\
\hline & \multicolumn{2}{|c|}{152 students } & \multicolumn{2}{|c|}{176 students } & \multicolumn{2}{|c|}{87 students } & \multicolumn{2}{|c|}{98 students } \\
\hline & $\mathrm{n}$ & $\%$ & $n$ & $\%$ & $\mathrm{n}$ & $\%$ & $\mathrm{n}$ & $\%$ \\
\hline Tilted head & 53 & 34.87 & 40 & 22.73 & 17 & 19.54 & 28 & 28.57 \\
\hline Rotated head & 31 & 20.39 & 32 & 18.18 & 27 & 31.03 & 23 & 23.47 \\
\hline Rotated and tilted head & 38 & 25.00 & 57 & 32.39 & 23 & 26.44 & 18 & 18.37 \\
\hline Elevated shoulders & 108 & 71.05 & 127 & 72.16 & 59 & 67.82 & 65 & 66.33 \\
\hline ASIS elevation & 116 & 76.32 & 113 & 64.20 & 57 & 65.52 & 56 & 57.14 \\
\hline Valgus knee & 81 & 53.29 & 86 & 48.86 & 34 & 39.08 & 35 & 35.71 \\
\hline Varus knee & 42 & 27.63 & 55 & 31.25 & 35 & 40.23 & 43 & 43.88 \\
\hline Head protraction & 89 & 58.55 & 101 & 57.39 & 55 & 63.22 & 45 & 45.92 \\
\hline Head retraction & 6 & 3.95 & 6 & 3.41 & 3 & 3.45 & 8 & 8.16 \\
\hline Protruded shoulder & 96 & 63.16 & 110 & 62.50 & 55 & 63.22 & 55 & 56.12 \\
\hline Posteriorized shoulder & 8 & 5.26 & 10 & 5.68 & 5 & 5.75 & 3 & 3.06 \\
\hline $\begin{array}{l}\text { Rectification of the } \\
\text { Cervical Spine }\end{array}$ & 36 & 23.68 & 44 & 25.00 & 29 & 33.33 & 35 & 35.71 \\
\hline Cervical lordosis & 36 & 23.68 & 23 & 13.07 & 9 & 10.34 & 11 & 11.22 \\
\hline $\begin{array}{l}\text { Rectification of the } \\
\text { Thoracic Spine }\end{array}$ & 51 & 33.55 & 43 & 24.43 & 26 & 29.89 & 33 & 33.67 \\
\hline Thoracic kyphosis & 41 & 26.97 & 48 & 27.27 & 23 & 26.44 & 15 & 15.31 \\
\hline
\end{tabular}


Table 4 - Frequency of postural alterations per school grade

(Conclusion)

\begin{tabular}{|c|c|c|c|c|c|c|c|c|}
\hline School grade & \multicolumn{2}{|c|}{$6^{\text {th }}$ grade } & \multicolumn{2}{|c|}{$7^{\text {th }}$ grade } & \multicolumn{2}{|c|}{$8^{\text {th }}$ grade } & \multicolumn{2}{|c|}{$9^{\text {th }}$ grade } \\
\hline Total number of & \multicolumn{2}{|c|}{152 students } & \multicolumn{2}{|c|}{176 students } & \multicolumn{2}{|c|}{87 students } & \multicolumn{2}{|c|}{98 students } \\
\hline Postural Alterations & $\mathrm{n}$ & $\%$ & $\mathrm{n}$ & $\%$ & $\mathrm{n}$ & $\%$ & $\mathrm{n}$ & $\%$ \\
\hline Pelvis in anteversion & 79 & 51.97 & 107 & 60.80 & 56 & 64.37 & 60 & 61.22 \\
\hline Pelvis in retroversion & 20 & 13.16 & 25 & 14.20 & 14 & 16.09 & 13 & 13.27 \\
\hline Knee semiflexion & 29 & 19.08 & 36 & 20.45 & 14 & 16.09 & 10 & 10.20 \\
\hline Knee hyperextension & 52 & 34.21 & 39 & 22.16 & 31 & 35.63 & 50 & 51.02 \\
\hline Cavus feet & 15 & 9.87 & 32 & 18.18 & 15 & 17.24 & 28 & 28.57 \\
\hline Planus feet & 94 & 61.84 & 89 & 50.57 & 44 & 50.57 & 42 & 42.86 \\
\hline
\end{tabular}

Note: $\mathrm{n}=$ number of students.

Source: Research data.

\section{Discussion}

Most postural problems, especially those related to the spine, have their origin in childhood. These alterations can be observed particularly after the individuals start school life. This is due to the amount of time spent in the sitting position. The condition worsens considerably if the chair and the table are not adjustable (1.20), which is often the case in everyday school life. Thus, many alterations arise and become established due to muscular action, resulting in exaggeration of spinal curvatures and lateral displacements of the spine, and leading to degenerative processes and misalignment of other body structures.

The main differences observed in this study were found in the following segments: head (tilt and protraction), shoulder (elevation and protrusion), pelvis (elevation and anteversion), knee (hyperextension and valgus) and feet (planus), confirming the findings in the literature.

A study by Penha et al. (20) assessed 132 female subjects aged 7-10 years and found the following deviations: valgus knee, medial hip rotation, antepulsion, pelvis in anteversion, knee hyperextension, lumbar hyperlordosis, valgus ankle, imbalanced shoulders, lateral pelvic inclination, scoliosis, trunk rotation, thoracic hyperkyphosis, winged scapula, shoulder protraction, abducted scapula, medial rotation of shoulders and head tilt.
Correia et al. (21) conducted a study with 73 male school children aged 7-10 years in the city of João Pessoa (PB). They detected the following deviations and pathologies: head tilt (30.1\%), elevated shoulders $(74 \%)$, adducted scapula $(57.0 \%)$ scoliosis (62.9\%), pelvic unleveling (24.6\%), knee hyperextension $(2.7 \%)$, varus knee $(20.5 \%)$, adducted feet (2.7\%), cervical hyperlordosis (30.1\%), dorsal hyperkyphosis (27.4\%), lumbar hyperlordosis (37.0\%)

Resende and Sanches (22) evaluated 2413 school children of both sexes aged 11-16 years and enrolled in state and private schools of Maringá (PR). They found that, as single deviations: $37.47 \%$ of the children had kyphosis $(45.74 \%$ of boys and $31.37 \%$ of girls); $21.44 \%$ had lordosis $(30.59 \%$ of girls and $9.04 \%$ of boys), and $10.84 \%$ of the children had scoliosis. Among the double deviations, they found: kyphosis-lordosis in $9.93 \%$ of the children $(12.94 \%$ of girls and $5.86 \%$ of boys) and kyphosis-scoliosis in $6.54 \%$ of the children $(11.70 \%$ of boys and $2.75 \%$ of girls). A very small number of children (1.13\%.) had three deviations (kyphosis, lordosis and scoliosis).

The most frequently found alteration in our study was elevated shoulders, observed in $77.78 \%$ of subjects. This corroborates the results of Santos et al. (23), which found this alteration in $50.2 \%$ of the 2471 st to 4 th graders assessed (131 boys and 116 girls) in a public school in the city of Jaguariuna (SP). According to Penha et al. (20), the presence of such asymmetry is related to the dominant side of 
the individual, usually occurring on the lower shoulder. Lemes and Pacagnan (24) observed increased frequency of elevated shoulders (94.23\%) on the left side, and the right side was the dominant side in $82 \%$ of individuals. Schmidt (25) studied the body posture of schoolchildren and found deviations in the upper segment, mainly in the shoulders and scapulas. Scapular deviations were highly related with the weight of the children.

Moreover, children usually carry backpack loads that are disproportionate to their body weight. This causes depression of one of the shoulders and may have consequences for the local muscles. The depression of the shoulders lengthens the muscles, such as the levator scapulae, the upper fibers of the trapezius and the rhomboids, and tend to work towards modulating such depression in order to protect the joints of the shoulder girdle through muscle contraction, i.e., a tendency to elevate the shoulder during excessive muscle contraction caused by prolonged use of school backpacks with excessive weights. Such muscles would be performing an eccentric work during depression, and later an isometric work to stabilize the shoulder (23).

With regard to the alterations found in the shoulder, we highlight protrusion in $61.60 \%$ of the children. This is due to the prevailing action of the serratus anterior and pectoralis major muscles on the rhomboid, and middle and superior trapezius, producing a medial rotation of the humerus and a anterior traction of the shoulder complex (23). This corroborates a study conducted by Xavier et al. (26) with 3611-year-old primary schoolchildren of both sexes from Ji-Paraná (RO). They observed that $77.77 \%$ of children had head protrusion.

The population of this study presented, in the sagittal plane, head anteriorization and shoulder protrusion, rectified kyphotic curvature and cervical curvature within normal range. This differs from the study reported by Verdéri (27), in which the increase in the kyphotic curvature produced alterations such as forward projection of the shoulder girdle and head (cervical hyperlordosis).

Pelvic anteversion was observed in more than half of the population studied. This increase in anterior pelvic tilt, associated with abdominal protrusion and knee hyperextension in children up to 9 years of age, leads to an increase in lumbar lordosis (in order to promote anteroposterior balance), which is considered a developmental disorder. From 9 years of age on, increased lumbar lordosis is considered an abnormal postural alteration which should receive therapeutic intervention in order to minimize the extent of the problem $(10,11)$.

Correa, Pereira and Silva (13) conducted a study on good and bad posture with 72 schoolchildren aged 8-15 years in Barra Mansa (RJ) and found 41.65\% of alterations, including hyperkyphosis, lordosis, scoliosis, valgus knees and valgus feet. They also observed scoliotic posture in $28.88 \%$ of girls and $13.88 \%$ of boys.

In a study by Rego and Scartoni (28) $475^{\text {th }}$ and $6^{\text {th }}$ graders were evaluated. They identified the prevalence of back pain, scoliosis and the imbalance of the anterior-superior iliac spine in $51 \%$ of the children; varus and valgus knees in 34\%, shoulder protrusion in $36 \%$, head anteriorization in $24 \%$ and varus and valgus feet in $32 \%$.

According Bienfait (29), the "physiological valgus knee" is characterized by an outwardly opened side angle, in order to compensate for the width of the hips and to turn the feet inward. Sacco et al. (30) studied a 18-year-old population and reported that knee alignment is directly related to the distribution of weight during gait and weight discharge on the feet.

The evaluation of the children's plantar arch revealed an increase in the prevalence of cavus feet from $9.87 \%$ in the $6^{\text {th }}$ graders to $28.57 \%$ in $9^{\text {th }}$ graders. Azevedo and Nascimento (31) perceived a progressive decrease in the degree of planus feet with increasing age, associating it to child development (height, weight, ligamentous laxity) and the performance or no performance of physical activity.

Furthermore, we identified the following accentuated postural alterations in children of all the grades studied: head and shoulders protraction, imbalanced shoulders and pelvis, pelvis in anteversion, knees hyperextension and planus feet. It is important to highlight that the frequency of shoulders protrusion, unilateral elevation of the pelvis and planus feet was high in children of all school grades. However, the prevalence of these alterations decreased with increasing school grades (from the $6^{\text {th }}$ to the $9^{\text {th }}$ grade): from $63.16 \%$ to $56.12 \%$ in the shoulders; from $76.32 \%$ to $57.14 \%$ in the ASIS; and from $61.84 \%$ to $42.86 \%$ in the feet. Conversely, the frequency of rectification of the cervical spine and of cavus feet increased with increasing school grades: from $23.68 \%$ to $35.71 \%$ in the cervical spine, and from $9.87 \%$ to $28.57 \%$ in the feet). 


\section{Conclusion}

In this work, we analyzed the postural alterations found in schoolchildren enrolled in a primary school in Vila Velha (ES). We evaluated the positioning of the head, shoulder, pelvis, lower limbs and cervical, thoracic and lumbar spines. The most frequent alterations found in the anterior and posterior views were: rotated or tilted head (70\%), elevated shoulder (77\%), elevated pelvis (67\%), valgus or varus knee $(80 \%)$. In the side view, we found: head protraction (56\%), alterations of the thoracic spine (54\%), anteriorized shoulders (61\%), pelvis in anteversion (58\%); knees semiflexion (17\%) or hyperextension (34\%); and cavus or planus feet (70\%).

These results suggest that there is a high prevalence of postural alterations in students in the school network of Vila Velha (ES). This could be modified through public health policies, such as the federal government's Health at School Program (PSE), which aims at the integration of health and education for the development of citizenship.

\section{Acknowledgments}

The authors are grateful to the FUNADESP National Foundation for the Development of Private Higher Education - for its aid and the financial support of this study.

\section{References}

1. Kendall FP, McCreary EK, Provance PG, Rodgers MM, Romani WA. Músculos: provas e funções. São Paulo: Manole; 2007.

2. Gross J, Fetto J, Rosen E. Exame musculoesquelético. Porto Alegre: Artmed; 2000.

3. Nissinen MJ, Heliövaara MM, Seitsamo JT, Könönen MH, Hurmerinta KA, Poussa MS. Development of trunk asymmetry in a cohort of children ages 11 to 22 years. Spine. 2000;25(5):570-4

4. Bunnell WP. Selective screening for scoliosis. Clin Orthop Relat Res. 2005;(434):40-5.

5. Shehab DK, Al-Jarallah KF. Nonspecific lowback pain in Kuwaiti children and adolescents: associated factors. J Adolesc Health. 2005;36(1):32-5.
6. Zapater RZ, Duane MS, Vitta A, Padovani CR, Silva JCP. Postura sentada: a eficácia de um programa de educação para escolares. Cienc Saude Coletiva. 2004; 9(1):191-9.

7. Cardon G, De-Clercq D, De-Bourdeaudhuij I, Breithecker D. Sitting habits in elementary schoolchildren: a traditional versus a "Moving school". Patient Educ Couns. 2004;54(2):133-42.

8. Murphy S, Buckle P, Stubbs D. Classroom posture and selfreported back and neck pain in schoolchildren. Appl Ergon. 2004;35(2):113-20.

9. Marshall SJ, Gorely T, Biddle SJ. A descriptive epidemiology of screen-based media use in youth: a review and critique. J Adolesc. 2006;29(3):333-49.

10. Detsch C, Candotti CT. A incidência de desvios posturais em meninas de 6 a 17 anos da cidade de Novo Hamburgo. Movimento. 2001;7(15):43-56.

11. Detsch C, Luz AMH, Candotti CT, Oliveira DS, Lazaron F, Guimarães LK. Prevalência de alterações posturais em escolares do ensino médio em uma cidade no Sul do Brasil. Rev Panam Salud Publica. 2007;21(4):231-8.

12. Schiaffino AN. Avaliação de desvios posturais em crianças entre 11 e 15 anos do Porto (dissertação). Porto: Faculdade de Medicina e Instituto de Ciências Biomédicas de Abel Salazar, Universidade do Porto; 2010.

13. Correa AL, Pereira JS, Silva MAG. Avaliação dos desvios posturais em escolares: estudo preliminar. Fisioter Bras. 2005;6(3):175-8.

14. Burns YR, MacDonald J. Fisioterapia e crescimento na infância. São Paulo: Santos; 1999.

15. Fornazari LP. Prevalência de postura escoliótica em escolares do ensino fundamental de duas escolas do município de Guarapuava - PR, 2005 (dissertação). Ribeirão Preto: Escola de Enfermagem, Universidade de São Paulo; 2005.

16. Reamy BV, Slakey JB. Adolescent idiopathic scoliosis: review and current concepts. Am Fam Physician. 2001; 64(1):111-6.

17. Altheman F. Lição de casa: cuidar de você!. Revista Crefito SP. 2009;6(1):10-5.

18. Prefeitura Municipal de Vila Velha (website). Unidades de Ensino Fundamental. (cited 2012 July 10). Available from: http://www.vilavelha.es.gov.br/paginas/ educacao-unidades-de-ensino-fundamental. 
19. Liposcki DB, Rosa Neto F, Savall AC. Validação do conteúdo do Instrumento de Avaliação Postural - IAP. Revista Digital. 2007;12(109):1-7.

20. Penha PJ, João SMA, Casarotto RA, Amino CJ, Penteado DC. Postural assessment of girls between 7 and 10 years of age. Clinics. 2005;60(1):9-16.

21. Correia PPB, Silva GCC, Nascimento JF, Lima NMM, Sousa MSC. Prevalência de desvios posturais em escolares da rede municipal de ensino da cidade de João Pessoa - PB. [cited 2010 Jan 2010] Available from: http://www.luzimarteixeira.com.br/wp-content/ uploads/2011/04/prevalencia-de-desvios-posturais-em-escolares-da-rede-municipal-de-ensino-dacidade-de-joao-pessoa-e28093-pb.pdf

22. Resende JA, Sanches D. Avaliação dos desvios posturais em crianças com idade escolar de 11 a 16 anos. Rev Educ Fis UEM. 1992;3(1):21-6.

23. Santos CIS, Cunha ABN, Braga VP, Saad IAB, Ribeiro MAGO, Conti PBM, et al. Ocorrência de desvios posturais em escolares do ensino público fundamental de Jaguariúna, São Paulo. Rev Paul Pediatr. 2009;27(1): 74-80.

24. Lemes A, Pacagnan AM. Análise das alterações posturais encontradas em estudantes de $3^{\underline{a}}$ a $6^{\underline{a}}$ série de escolas públicas de Foz do Iguaçu - PR. In: Anais do 4. Seminário de Fisioterapia Uniamérica: Iniciação Científica, 24-25 maio 2010 (cited 2014 Aug 22), Foz do Iguaçu, Brasil. Available from: http://www.uniamerica.br/site/pdf/geral/381160ff39.pdf

25. Schmidt A. Estudo das alterações morfológicas do sistema locomotor em escolares do ensino fundamental: faixa etária entre 7 e 14 anos de ambos os sexos do município de Marechal Candido Rondon, PR - através da avaliação postural computadorizada (dissertação). Campinas: Universidade Estadual de Campinas; 1999.
26. Xavier CA, Bianchi DM, Lima AP, Silva IL, Cardoso F, Beresford H. Uma avaliação acerca da incidência de desvios poturais em escolares. Revista Meta. 2011; 3(7):81-94.

27. Verdéri E. Programa de educação postural. São Paulo: Phorte; 2001.

28. Rego ARON, Scartoni FR. Alterações posturais de alunos de $5^{\underline{a}}$ e $6^{\underline{a}}$ séries do Ensino Fundamental. Fit Perform. J. 2008;7(1):10-5.

29. Bienfait M. Os desequilíbrios estáticos: fisiologia, patologia e tratamento fisioterápico. São Paulo: Summus; 1995.

30. Sacco ICN, Trombini-Souza F, Ribeiro AP, Gomes AA, Roveri MI, Silva DRMV, et al. Alinhamento frontal estático do joelho e cargas plantares durante a marcha de adultos jovens assintomáticos. Fisioter Pesqui. 2009;16(1):70-5.

31. Azevedo LAP, Nascimento, LFC. A distribuição da força plantar está associada aos diferentes tipos de pés? Rev Paul Pediatr. 2009;27(3):309-14.

Received: 02/18/2013

Recebido: 18/02/2013

Aprovado: 05/09/2013

Approved: 09/05/2013 